\title{
PAŃSzCZYZNA I PRZEMOC. HISTORIE LITERACKIE I WSPOMNIENIOWE Z XIX WIEKU
}

\section{PAWE⿺ TOMCZOK}

\begin{abstract}
Abstrakt: Artykułu przedstawia model przemocy pańszczyźnianej, który można skonstruować na podstawie fragmentów dziewiętnastowiecznych powieści oraz wspomnień chłopów pamiętających doświadczenie pańszczyzny. Powieść realistyczna nie podejmuje bezpośrednio zagadnienia pańszczyzny jako głównego tematu przedstawienia, dlatego też reprezentacji przemocy pańszczyźnianej należy szukać na granicy świata głównych bohaterów, zwykle wywodzących się z klas uprzywilejowanych. Te krótkie fragmenty znanych powieści pokazuja oczywistość przemocy wobec chłopów. Przemoc stanowi tu sposób utrzymania własnej pozycji społecznej, a jednocześnie poniżenia osób wykonujących pracę fizyczna. W tekstach wspomnieniowych można natomiast znaleźć opisy sposobu oddziaływania przemocy na chłopów. Analizuje dwa przykłady tłumienia chłopskiego buntu z wykorzystaniem przemocy fizycznej doprowadzającej ofiary do stanu bliskiego śmierci. Pozostawionych przy życiu chłopów pozbawiono wszelkiej nadziei i aktywności, by z rezygnacja pogodzili się z przymusem pracy. Ten schemat powiązania pracy i przemocy nie znika wraz ze zniesieniem pańszczyzny, gdyż nowe stosunki kapitalistyczne podtrzymuja nierówność między kapitalistą a proletariuszem.
\end{abstract}

Słowa kluczowe: pańszczyzna, przemoc, powieść realistyczna, literatura ludowa 
Zniesienie pańszczyzny stanowi jedną z najważniejszych „narracji emancypacyjnych” dziewiętnastego wieku ${ }^{1}$. Poddaństwo i praca przymusowa, bezpośrednia przemoc fizyczna stały się w tej epoce pojęciami negatywnymi (Blickle 2003) - oznakami rzeczywistości, która musi przeminać, by zastapić ją mogły nowe idee: wolności i równości. Ale idee wolności pozostały w dziewiętnastym wieku tylko dyskursem zasłaniającym faktyczność różnych form niewoli. Zastapienie pracy przymusowej „dobrowolną” umową do dziś stanowi jeden z najważniejszych ideologicznych obrazów wolności jednostki w kapitalistycznym świecie uwolniona $z$ ograniczeń feudalnych i państwowych osoba powinna bowiem swobodnie dysponować swoja praca, by sprzedawać ja za najbardziej dogodna cenę i w najlepszych warunkach. Trudno tu przytoczyć rozliczne dowody na to, że wolna praca jest wyłącznie fikcją - przede wszystkim wolność umowy nie mogła zaistnieć z powodu słabej pozycji proletariusza, pozbawionego środków produkcji i zmuszonego do sprzedaży swojej pracy. Ale fikcyjność owej wolności ujawnia się również w licznych formach długoletnich zobowiązań, które ograniczały swobodę pracownika, a jego status zbliżały do niewolniczego. Także różne formy długu ograniczały zarówno wolność pracy, jak też wolność osobistą ${ }^{2}$. Pod maską wolnej umowy i swobody pracy skrywały się zatem różne formy przymusu do pracy wykorzystujące przemoc bezpośrednią (Gerstenberger 2017, 18).

Problematyka powiązania przemocy, wolności i pracy często pojawia się w literaturze polskiej drugiej połowy dziewiętnastego wieku. Część autorów z wielkim zaangażowaniem próbowała zapisywać proces „uwłaszczenia literackiego” dawnych chłopów pańszczyźnianych, ale wielu skupiło się na pokazaniu nowych form wyzysku - nie zapominając wcale o negatywnym charakterze stosunków społecznych przed uwłaszczeniem. Chyba najlepiej znanym utworem wyrażającym to rozczarowanie pozorną emancypacja jest wiersz Marii Konopnickiej Wolny najmita. Wielokrotnie przedrukowywany, także w antologiach poezji socjalistycznej, wiersz ukazuje uwolnienie od feudalnych zależności jako początek bezdomności, bezrobocia, społecznej izolacji. Nie chodzi w nim jednak o wychwalanie dawnej pańskiej opieki nad chłopem! W podobny sposób chciałbym pisać o powiązaniu pracy i przemocy w tym artykule - przedstawianie wciąż trwającej przemocy w świecie po pańszczyźnie nie ma zasłaniać nadobecności przemocy w rzeczywistości feudalnej. Chodzi jedynie o wykazanie ciągłości, być może długiego trwania, ale nie mentalności pańszczyźnianej, a struktury społecznej, w której proletariat fabryczny i rolny, a także służba wciąż podlegają różnym formom przymusu pracy. Pracownik bity, oszukiwany,

\footnotetext{
${ }^{1}$ Ostatnio o opowiedzenie dziejów zniesienia pańszczyzny jako emancypacji upominał się Andrzej Leder w artykule Nienapisana epopeja. Uwtaszczenie miałoby stać sie jednym z elementów genealogii polskiej klasy średniej (Leder 2016).

2 Heide Gerstenberg w książce Market und Gewalt poświęconej obecności przemocy w „historycznym kapitalizmie" przytacza liczne przykłady wykorzystania niewolnictwa i form do niego zbliżonych w gospodarce kapitalistycznej. Autorka obszernie opisuje również fikcję wolności pracy opartej o umowę (Gerstenberg 2017).
} 
zmuszany do podpisywania niekorzystnych, wręcz niewolniczych umów - tylko pozornie może czuć się wolny, gdyż feudalne obowiązki zastąpiły nowe formy kapitalistycznego zniewolenia.

W artykule chciałbym omówić literacką historię przemocy pańszczyźnianej, która utrzymywała cała grupę w mentalnej, a także fizycznej zależności. W przeciwieństwie do historiografii pańszczyzny, opartej na badaniu prawa i ekonomii, teksty literackie dotyczące przemocy pańszczyźnianej nie zostały opisane jako spójny temat ${ }^{3}$. Tymczasem literatura dostarcza dodatkowej wiedzy o pańszczý́nie, pokazując, jakie znaczenie ma doświadczenie przemocy zarówno dla jej sprawców, jak też ofiar - jak utrwala podziały społeczne, a potem nie pozwala wyłonić się nowym podmiotowościom. Teksty literackie można zatem potraktować jako źródło badań znaczenia pańszczyzny i jako kulturową pamięć, w której to doświadczenie nawiedza kolejne pokolenia. Nie można jednak budować modelu długiego trwania pańszczyzny już po jej zniesieniu - tak jakby w „wolnych”, kapitalistycznych stosunkach pracy przemoc istniała tylko w pamięci czy mentalności. Długie trwanie pańszczyzny w drugiej połowie dziewiętnastego wieku, a także później, to nie tyle kwestia „duszy pańszczyźnianej”, co raczej charakteru stosunków między pracą a kapitałem, opartych na przemocy ze strony kapitalistów, często niewiele różniących się od panów feudalnych. Zamiast o długim trwaniu mentalności pańszczyźnianej (przede wszystkim po stronie chłopów i robotników, ale także po stronie grup uprzywilejowanych) należy mówić o formach przemocy obecnych w ekonomicznych relacjach społeczeństwa pofeudalnego te formy często przypominają feudalną przemoc i wytwarzaja podobne struktury psychiczne w nowym systemie społeczno-gospodarczym.

Przemoc pańszczyźniana nie stanowi dominującego tematu literatury dziewiętnastego wieku. Mimo że obecna w wielu uznanych utworach ${ }^{4}$, najczęściej zajmuje miejsce na marginesach przedstawienia. Wyczytanie pańszczyzny z wielkich utworów realistycznych wymaga zatem zwrócenia uwagi nie na fabułę i głównych bohaterów, lecz na sceny, sytuacje i zwykle anonimowe postaci, o których przeżyciach niewiele się dowiadujemy. Znacznie częściej ukazywane są afekty sprawców przemocy, co wynika choćby z tego, że większość autorów literatury polskiej dziewiętnastego wieku wywodzi się z kręgów szlacheckich, które głęboko uwewnętrzniły oczywisty stosunek pana feudalnego oraz jego urzędników do chłopów. Ale nawet te skromne zapisy ujawniają, jak ważną rolę ogrywa

\footnotetext{
${ }^{3}$ Przegląd problematyki pańszczyźnianej w literaturze znajduje się np. w przedmowach do dwóch antologii Wieś pańszczyźniana w literaturze polskiej (Piszczkowski 1972) oraz Wzięli diabli pana (Czernik i Przyboś 1955).

4 Większość ważnych fragmentów literackich dotyczących pańszczyzny zamieszczona została we wspomnianych w poprzednim przypisie antologiach. Najbardziej znany projekt rozwiązania obciążeń feudalnych stanowi oczywiście zakończenie Pana Tadeusza Adama Mickiewicza.
} 
przemoc w konstytucji podziałów społecznych, a także psychologii grup dominujących oraz zdominowanych 5 .

W tworzonej przez chłopów literaturze ludowej ${ }^{6}$ pańszczyzna pojawia się znacznie częściej, ale właściwie w dziewiętnastym wieku też nie może zostać w pełni wypowiedziana. Stanisław Czernik pisze, że:

Pieśń o pańszczyźnie nie mogła się ani rozwijać, ani zachować przy ówczesnym systemie kontroli nad chłopem. Nie było miejsca na taką pieśń. Nie można jej było śpiewać ani w polu, ani w karczmie, ani podczas zabawy; w każdym razie wypowiedź jawna groziła bardzo poważnymi następstwami. Ustrój feudalny trzymał chłopów w niewolniczych karbach, za pośrednictwem rozwiniętego systemu różnych „przystawców” - polowych, karbowych, ekonomów, włodarzy, pisarzy, którzy pilnowali nie tylko pracy, ale byli równocześnie nadzorcami „moralności” chłopów, łącznie z plebanią, jej sługami i zausznikami, łącznie także z karczmą.

Ustrój feudalny utrzymywał się środkami nieustannego budzenia grozy, stosowaniem nieludzkich kar przy najdrobniejszych przewinieniach wobec dworu. Dyby, gąsior, ciemniczka, surowe plagi cielesne, nawet „szubieniczka” - pospolite to były sposoby pilnowania „ładu i porządku” (Czernik 1951, 63).

System feudalnej przemocy zniewala nie tylko ciało, ale też język, możliwość wypowiedzenia - ma odebrać możliwość pisania, a nawet myślenia. Nie może być zatem mowy o rozwinięciu jakiejś ludowej kultury tworzącej wyraźną alternatywę dla dominującej kultury warstw uprzywilejowanych. Głos ludu zwykle zostaje stłumiony, osłabiony przez aparat nadzoru i represji. Nic dziwnego zatem, że zapisów doświadczenia pańszczyzny trzeba szukać w czasach popańszczyźnianych, gdyż dopiero wtedy pamięć przemocy mogła zostać wypowiedziana. Jako przykłady takich artykulacji można podać wspomnienia osób, które z różnych powodów nie podlegały już obowiązkowi odrabiania pańszczyzny, gdyż albo udało im się wyemigrować z kraju, albo też pisały w późniejszych czasach.

Próba napisania historii chłopów napotyka zatem wieloaspektowy problem źródłowy. Ważniejszy wydaje się jednak inny kłopot - formy narracyjnej, w której można ująć dzieje chłopów. Wielokrotnie podkreślano, że stanowią one wyparty temat polskiej historiografii, szczególnie ostatnich lat. Skutkiem tego ma być przekłamująca obraz rzeczywistości dysproporcja - wielkiej części społeczeństwa poświęca się znikomą ilość miejsca w historiograficznych syntezach (zob. np. Rauszer 2016, 97). Tego zafałszowania nie

\footnotetext{
${ }^{5} \mathrm{Na}$ temat sposobów przedstawiania chłopów w literaturze pierwszej połowy dziewiętnastego wieku zob. Wołk-Gumplowiczowa 1939.

${ }^{6}$ Definicję literatury ludowej omawia Stanisław Pigoń (Pigoń 1974, 23).
} 
da się jednak łatwo usunaćc. Napisanie autonomicznej historii chłopów czy dziejów gospodarstwa wiejskiego (co oczywiście już zostało zrobione) raczej nie rozwiąże problemu, szczególnie gdy miałyby one przyjąć formę jakichś heroicznych kronik kolejnych buntów chłopskich.

We współczesnych badaniach historii chłopów rozważa się dwie główne narracje. Pierwsza - historia cierpienia i przemocy - stanowi raczej element negatywny względem drugiej - historii buntu i oporu. W ramach pierwszej narracji system feudalny jest przedstawiany jako tak skuteczny mechanizm dominacji, że pozycja chłopów stawała się za jego sprawa całkowicie bierna. Jan Wasiewicz traktuje ten obraz chłopa-ofiary jako narzucony, służący wyrzucaniu z pamięci buntów chłopskich, a doskonale wpisujący się w oczekiwania dotyczace cech chłopa: istoty biernej, bezmyślnej, a jednocześnie chciwej (Wasiewicz 2014, 152; zob. też Burszta 1985, 76). Pierwsza narracja okazuje się w takiej perspektywie kontynuacja dyskursywnej przemocy wobec chłopa, uznawanego za istotę z natury tępa i posłuszna, niezdolną do buntu, a za to świetnie przystosowaną do znoszenia upokorzeń i ciężkiej pracy. Tę narrację coraz częściej zastępuje się innym wzorcem, nawiązującym do popularnego w latach powojennych ${ }^{7}$ modelu eksponowania chłopskich walk społecznych, traktowanych wtedy jako (proto)forma walk klasowych, które w pełni rozwinie proletariat fabryczny. Przeprowadzone przez historiografię PRL liczne badania oporu chłopskiego moga dziś stanowić świetny materiał dla drugiego modelu historii chłopów - i służyć za podstawę przywracania pamięci oporu przeciw pańszczyźnie (Rauszer 2016).

W tym artykule chciałbym trochę inaczej rozłożyć akcenty, zasugerować trochę inną dialektykę - zaproponować trzecią narrację. Zamiast drugiego modelu, w którym odpowiedzią na wyzysk są opór i walka, wykorzystuję model triadyczny. W historiografii powojennej chętnie podkreślano, że nawet nieudane wyrazy sprzeciwu wymusiły ustępstwa np. ograniczenie rugów w 1846 roku w Królestwie Polskim czy uwłaszczenie w trzech zaborach. Te interpretacje świetnie pasuja do historii postępu i emancypacji - narracji o wyzwoleniu chłopa z feudalnych więzów, które dokonuje się zarazem dzięki walce klasowej, jak i koniecznemu przejściu od feudalizmu do kapitalizmu. Inaczej niż w ramach tradycyjnego marksizmu i jego dzisiejszych pogłosów wolałbym skupić się na aparatach dominacji i formach podporządkowania pracy opartych na przymusie fizycznym - dominacji, której jednym z elementów albo etapów jest bunt: stłumiony brutalną przemoca.

Triadyczny model dialektyki pańszczyźnianej przemocy wychodzi od struktury zapisanej w kilku przedstawieniach literackich i wspomnieniowych. A także od analizy licznych historycznych sytuacji oporu, które prawie zawsze kończyły się przegraną chłopów -

\footnotetext{
${ }^{7}$ Nie można zapominać o ważnych pracach przedwojennych opisujących bunty chłopskie w dziewiętnastym wieku (Meloch 1939; Grynwaser 1951).
} 
czy chodziło o skargi, procesy sądowe, odmowę pracy, czy bunty. Pierwszy moment tej dialektyki stanowi doświadczenie wyzysku, przymusu pracy. Drugi to opór, pojawiający się $\mathrm{z}$ różnych powodów (np. indywidualna lub zbiorowa krzywda, pogłoski o zniesieniu pańszczyzny). Trzeci moment wyznacza pacyfikacja ${ }^{8}$ buntu, wymierzenie kary i przywrócenie „porządku”. Zauważmy jednak, że przywrócenie porządku często ustanawia już inny świat który można znowu zinterpretować dwojako. Może on przywodzić na myśl pamięć o chłopskiej sile, zdolnej wprawić panów w lęk - wtedy mamy do czynienia z utrzymaniem pamięci oporu i nadziei zmiany. Ale co najmniej tak samo ważne jest inne rozłożenie akcentów pamięci - zogniskowane na doświadczeniu kolejnej, zwykle brutalnej przemocy, której ofiary, skatowane aż do stanu graniczącego ze śmierci, wracają do życia jako jednostki bierne, złamane, zniszczone - zdolne już tylko do bezwolnego wykonywania przymusowej pracy. Zamiast zastanawiać się, czy chłopi jako grupa byli bardziej bierni czy zbuntowani, albo pytać, komu służą poszczególne obrazy chłopów, w dialektycznym modelu owe obrazy można zinterpretować jako elementy dramatycznego przedstawienia, w którym mieszczą się różne role i tożsamości: ofiary, buntownika, biernego ciała wykonującego pracę.

Kto jest bohaterem tej dialektycznej fabuły? W kontekście ruchu wyzysku, oporu i pacyfikacji można mówić o różnych momentach upodmiotowienia. Pierwszy moment pozytywnej podmiotowości rodzi się w momencie buntu - to podmiotowość nadziei na przełamanie poniżenia. Ale pacyfikacja tej pozytywnej podmiotowości prowadzi do kolejnej formy, negatywnej podmiotowości - ciało zostało skazane na śmierć, ale śmierć ciała zastapiono zniszczeniem jego pozytywnej podmiotowości.

Przezwyciężeniem tej fatalnej dialektyki, w której pacyfikacja buntu utrwala zniewolenie, może wydawać się uwłaszczenie. Liczne świadectwa pokazuja jednak, że zniesienie pracy przymusowej oznaczało często wprowadzenie nowych form przymusu pracy, a nadzieje wiązane $z$ emancypacyjną stroną tego procesu nie spełniły się. „Literackie uwłaszczenie chłopów” (Pigoń 1974, 239) zaczyna się dopiero w latach osiemdziesiątych dziewiętnastego wieku - i przebiega bardzo powoli, z wieloma trudnościami: mimo powstania chłopskich organizacji politycznych i społecznych wielu autorów podkreśla długie trwanie traumy związanej z przemocą doświadczaną przez przodków, a dla określenia sytuacji chłopów znacznie ważniejsze jest zwrócenie uwagi na ich doświadczenie różnych form biedy w systemie kapitalistycznym.

W pierwszej części artykułu zarysowane zostaną historyczne aspekty przemocy pańszczyźnianej w dziewiętnastym wieku. W drugiej części przedstawię interpretację fragmentów prozy realistycznej przedstawiających przemoc wobec chłopów - dwa pierwsze przypadki odnoszą się do świata przed uwłaszczeniem, trzy kolejne ukazują trwanie

\footnotetext{
${ }^{8}$ Stanisław Pigoń zwraca uwagę na dialektykę rabacji i pacyfikacji (Pigoń 1983, 84, 86).
} 
mentalnych struktur przemocy, które odradzają się w rzeczywistości już po przeprowadzonym uwłaszczeniu. W trzeciej części artykułu omówione zostaną przedstawienia przemocy pańszczyźnianej w literaturze ludowej - poezji i wspomnieniach.

\section{Historie pańszczyzny}

Z punktu widzenia walki klas historia nowożytnej Polski to dzieje wtórnego poddaństwa zwiększania obciążeń pańszczyźnianych chłopów oraz prawnego utwierdzania dominacji szlachty nad poddanymi. Pod koniec średniowiecza rodzi się nowy podział Europy ze względu na formę gospodarki czynszowej (Grundherrschaft) i folwarcznej (Gutsherrschaft) (Grynwaser 1951, 14). Występująca w szesnastym i siedemnastym wieku koniunktura na produkcję wiejską (Leskiewiczowa 1964, 28) zostaje na różne sposoby wykorzystana w Europie Zachodniej i Wschodniej. Na Zachodzie konflikt między szlachtą a innymi grupami społecznymi - chłopami i mieszczaństwem - nie doprowadza do dominacji szlachty (Topolski 1982), natomiast w środkowych i wschodnich regionach Europy szlachta zdobywa dominująca pozycję, podporządkowując sobie zarówno mieszczaństwo, jak i chłopów.

W Polsce rozwój gospodarki pańszczyźniano-folwarcznej wiązał się w możliwościa eksportu zboża przez Gdańsk. Dochody z wywozu zboża czerpali głównie właściciele wielkich gospodarstw położonych w dorzeczu Wisły. Umożliwiło to powstanie nowych wielkich majątków i systemu politycznego, który zapewniał ochronę tego porządku. W ostatnim czasie nowe badania nad pańszczyzną wskazały, że przyczyną powstania folwarku mógł być także wewnętrzny kryzys, a nie wyłącznie bałtycka koniunktura (Kowalewski, s. 49-50). Inni autorzy podważaja natomiast oczywistość granicy na Labie jako linii oddzielającej rozwinięte i zacofane rejony Europy (Cerman 2012) oraz zmierzaja w stronę koncepcji nowego modelu pracy pańszczyźnianej, w którym chłopom przypisywano aktywną rolę. Prace te sygnalizuja potrzebę mikrohistorycznych badań nad pańszczyzną w miejsce badań długofalowych, w których znikają historyczne i lokalne różnice.

Stanisław Śreniowski przytacza myśl Jana Zamoyskiego, zgodnie z która ,,poddaństwo chłopów jest podstawą wolności szlacheckiej”. A dalej komentuje: „Niewola chłopa była podstawą egzystencji szlachty. Majątki pańskie przybrały - jak powiedzieliśmy - kształt zamkniętych państewek, a należałoby je określić dosadniej; każde z nich przybrało kształt getta chłopskiego" (Śreniowski 1947, 105). Folwarki stały się zatem autonomicznymi państewkami, w których chłopi coraz bardziej zależni byli od pana feudalnego i jego administracji. Ta nieograniczona władza wyrażała się w ideologii uznającej odrębność rasy panów i chamów, a także rozwinęła „swoistą technikę kierowania życiem społecznym tej masy ludzkiej” (Burszta 1985) - opartą na zhierarchizowanej służbie dworskiej i dystrybucji 
przemocy. Pańszczyzna stawała się w tym systemie formą bliska niewoli9. Pańszczyźniany niewolnik musiał jednak wyżywić się samodzielnie (Sismondi 1955, 176-177). Jacek Kochanowicz podsumowuje położenie chłopa w gospodarce przedrozbiorowej jako walkę o przetrwanie:

Dla zdecydowanej większości gospodarstwa w osiemnastowiecznej Polsce celem było przetrwanie. Powiadam „przetrwanie”, nie zaś „samozaopatrzenie”, ponieważ znaczna część rodzin chłopskich, zwłaszcza u schyłku epoki folwarczno-pańszczyźnianej, nie dysponowała ilością ziemi wystarczającą do utrzymania się wyłącznie z produkcji rolnej (Kochanowicz 1992, 118).

Peter Blickle w książce o historii wolności w Niemczech zatytułowanej Od poddaństwa do praw çłowieka twierdzi, że poddaństwo pod koniec osiemnastego wieku stało się negatywnym pojęciem przewodnim dla tendencji modernizacyjnych (Blickle 2003, 153). Jako pozostałość po feudalizmie było likwidowane wraz z wprowadzaniem w kolejnych państwach praw opartych na Kodeksie Napoleona. Pojawiła się w tym czasie refleksja filozoficzna (zob. hasło dotyczące własności, Schwab 1975), która traktowała każdego człowieka jako podmiot własności, a także pokazywała granice sprzedawania własnej pracy i siebie (Kant 2011, 432; na temat nowożytnego pojęcia własności: Locke 1992, 180). Od poddaństwa droga prowadzi zatem do podmiotu własności i wolności (o powiązaniu własności i wolności pisze Blickle 2003, 277).

Zabory wcale nie naruszyły feudalnego porządku Rzeczpospolitej Obojga Narodów ${ }^{10}$, a raczej „zmumifikowały feudalizm” (Śreniowski 1947, 107) - choć często systemy prawne zaborców, np. Austrii ograniczały możliwość wyzysku chłopów. Pamiętać należy zatem, że w pierwszej połowie dziewiętnastego wieku nie istnieje jeden spójny model pańszczyzny, lecz dochodzi do skomplikowanego zróżnicowania form pracy - nie tylko w różnych zaborach, ale także w dobrach królewskich i prywatnych, a nawet w poszczególnych regionach sytuacja chłopów może się różnić z powodu ukonstytuowania się różnych tradycji.

Spośród wielu reform zmieniających charakter pracy przymusowej na początku dziewiętnastego wieku chyba najważniejszym wydarzeniem jest zniesienie poddaństwa 21 grudnia 1807 roku, gdy reformy napoleońskie trafiają także do Księstwa Warszawskiego.

\footnotetext{
${ }^{9}$ Siła szlachta powodowała zwiększenie poddaństwa, które zbliżało się do kompletnego niewolnictwa (zob. Grynwaser 1951, 19). Aktualne dyskusje na temat przedstawia Waldemar Kuligowski (Kuligowski 2016).

10 Oczywiście sytuacja w każdym zaborze wyglądała trochę inaczej. Gdy patrzy się tylko na daty zniesienia pańszczyzny w poszczególnych zaborach, wydawać się może, że dzieli je różnica kilkudziesięciu lat. Pamiętać jednak należy, że likwidacja pańszczyzny - nawet w zaborze pruskim, gdzie rozpoczęła się najwcześniej - była procesem rozciągniętym w czasie. W tym artykule skupię się na doświadczeniach Królestwa Kongresowego, w mniejszym stopniu ziem zabranych oraz Galicji.
} 
W wyniku wpływów grup posiadających reforma odbywa się bez przyznania chłopom praw do ziemi (Śreniowski 1947, 127). Dotychczasowa dwuwłasność, własność podzielona, regulowana obyczajem, a nie spisanym prawem (Grynwaser 1951, 12), zostaje zastapiona nową formą własności. Grynwaser tak ocenia nowe prawo: „Dekret z dnia 17/21 grudnia 1807 r. był aktem przemocy stanowej, gdyż pomijał zupełnie aktualne panujące na wsi stosunki gruntowe spółwłasnościowe i urzeczywistniał najśmielsze pragnienia szlachty folwarcznej w dziedzinie gruntowej" (Grynwaser 1951, 41). A dalej dodaje, że dekret „włościan ze współwłaścicieli zepchnął do roli chwilowych, prekaryjnych dzierżawców” (Grynwaser 1951, 51).

Zniesienie poddaństwa w 1807 roku tylko pozornie wprowadzało prawo nowoczesnego kapitalizmu11. Faktycznie interes szlachty decydował o stosowaniu feudalnej wykładni prawa (Kochanowicz 1981, 83), co prowadziło do „regresu feudalnego” (Stankiewicz 1968, 163) trwającego do 1846 roku. Mimo że „Pańszczyzna, ściśle biorąc, była w nowych warunkach bezprawiem. [...] Pańszczyzna utrzymała się, pozostając jakby poza prawem. [...] O trwaniu pańszczyzny decydowało więc prawo silniejszego" (Kieniewicz 1953, 5), na dodatek od 1818 roku właściciele wsi stawali się wójtami, zyskiwali także władzę sądownicza nad chłopami (Kieniewicz 1953, 7). Przestrzegana przez państwo zasada nieingerencji sprawiała, że chłopi, mimo zniesienia poddaństwa, byli całkowicie zależni od władzy właściciela ziemi.

Nowe możliwości eksploatacji chłopstwa szczególnie zintensyfikowały się w latach trzydziestych, gdy lepsza koniunktura na zboże połączyła się z ograniczeniem działalności politycznej. Przewaga właścicieli ziemi została wykorzystana do stworzenia nowej organizacji gospodarstw poprzez dzielenie ziemi i przenoszenie albo wyrzucanie chłopów. Jak zauważa Jacek Kochanowicz, w dziewiętnastym wieku porządek feudalny stracił „swój symetryczny charakter - wieś, podporządkowana woli właściciela lub dzierżawcy, zmuszona do odrabiania powinności, nie miała już prawa do ulg i opieki dworu, tak jak ograniczone zostały jej uprawnienia do pastwisk i lasów" (Kochanowicz 1981, 85). Ten brak przywiązania miał być szczególnie widoczny we wioskach dzierżawionych albo nabytych przez nowych właścicieli (Kieniewicz 1953, 15-16; Grynwaser 1951, 94), którzy bezwzględnie eksploatowali pracę, traktując ludność jak bydło: „Powszechnie widzieć się dają na dworskich łanach napędzone gromady ludzi, jak trzody bydła poganiane biczem przez groźnych dozorców, nieszczęśliwy zwyczaj równie upadlający robotników jak panów” (Koźmian 2000, 327) - pisze Kajetan Koźmian, jeszcze przed powstaniem listopadowym walczący o poprawę sytuacji chłopów.

\footnotetext{
11 Przypomnijmy, że Stanisław Staszic widział w zniesieniu poddaństwa koniec feudalizmu. Zob. Staszic 1954, 290.
} 
Główną formą przemocy wobec chłopów - oprócz częstego bicia - były w tym czasie rugi ${ }^{12}$, wywłaszczenie prowadzące do akumulacji ziemi w rękach wielkich posiadaczy - można je porównać do grodzenia (Polanyi 2010). To przemoc, która przygotowuje kapitalizm, podczas gdy pierwsza jej forma podtrzymuje feudalizm. Tomasz Potocki tak przedstawia położenie wypędzonych chłopów:

\begin{abstract}
Zdarzało się, że dziedzice nadużywając swej władzy nie pod ściśle prawnym, ale pod moralnym, pod chrześcijańskim względem, całe gromady porozpędzali; widziano wsie z ziemią zrównane i całe ludności błąkające się bez przytułku, dopóki kto pojedynczo pustej roli czy pustej komory w innym miejscu nie znalazł ${ }^{13}$.
\end{abstract}

Możliwości legalnego oporu przeciwko właścicielom czy dzierżawcom majątków były niewielkie, gdy cała władza sądownicza znajdowała się w rękach przedstawicieli uprzywilejowanej klasy. Opis takiej wieloletniej sądowej walki przedstawia Kazimierz Deczyński (Deczyński 1978), chłopski syn i nauczyciel, próbujący pomagać swojej rodzinie w obronie przed bezwzględnym wyzyskiem. Jego pamiętnik jest jednak zapisem bezradności - w wyniku działań swoich antagonistów zostaje powołany do wojska, a jego świadectwo spisane na emigracji, ale odrzucone przez środowisko, zostaje wydane dopiero na początku dwudziestego wieku. Te upokorzenia skutkują nienawiścią chłopów do szlachty, a także problematyczną tożsamością narodową chłopów ${ }^{14}$.

Niepokoje chłopskie pojawiaja się w czasie powstania listopadowego, w latach czterdziestych, gdy ogłoszono akt prawny zakazujący wywłaszczania z większych gospodarstw ${ }^{15}$, a także przed powstaniem styczniowym. Największe oddziaływanie miało jednak wydarzenie z zaboru austriackiego, rabacja 1846 roku, gdy przemoc chłopów skierowała się bezpośrednio przeciwko szlachcie i przybrała krwawa postać. To traumatyczne zdarzenie dla polskich elit - zarówno krajowych, jak emigracyjnych - miało dalekosiężne skutki. Przede wszystkim wielu odebrało nadzieje na zbudowanie projektów politycznych

\footnotetext{
12 Grynwaser zwraca uwagę na ograniczony charakter wywłaszczeń: „W okresie konstytucyjnym Królestwa od rugów i regulacji ucierpieli poważnie tylko włościanie województw o wyższej kulturze rolnej, mazowieckiego, kaliskiego i płockiego. Na wschodzie kraju nowe prądy gospodarcze dopiero się zaczynały. Temu przypisać należy, że w okresie czterdziestoletnim od dekretu 1807 r. do zakazu usuwania włościan zaledwie część włościan rolnych została wyrugowana, znaczna większość pozostała na gruncie" (Grynwaser 1951, 68).

${ }^{13}$ T. Potocki (Krzyżtopór): O urzqdzeniu stosunków rolniczyych w Polsce. 1859, s. 344. Cyt. za Kieniewicz 1953, 17.

${ }^{14} \mathrm{Na}$ temat walka klasowych w czasach powstania zob. Meloch 1939 (szczególnie historię trzystu chłopów, którzy przybyli do Warszawy). Literackie opracowanie tematu stanowi międzywojenna powieść Leona Kruczkowskiego Kordian i cham.

15 Grynwaser pisze, że ogłoszenie ukazu w 1846 roku wywołało pierwszy zbiorowy ruch włościan w Królestwie Polskim (Grynwaser 1951, 121, 126).
} 
w oparciu o lud ${ }^{16}$. Dotychczas lekceważona grupa społeczna łatwo mogła dać się przekonać administracji zaborczej, której pomoc umożliwiała szlachcie podtrzymanie systemu wyzysku. Wykopana została „przepaść między chłopem a reszta społeczeństwa” (Bojko 1947, 98), a Iwan Franko dodaje, że zwrócenie uwagi elit na lud wiązało się ze zmianą afektywnego odniesienia z pogardy na nienawiść (Franko 1979, 166).

Ujawnienie się antagonizmów społecznych 1846 roku, a także wcześniej, przy okazji spisku księdza Piotra Ściegiennego, i później, w czasie Wiosny Ludów, wywołało poczucie zagrożenia kwestią włościańską, traktowana jako peryferyjna wersja zagrożenia socjalizmem. Propozycje reform miały z jednej strony zapewnić utrzymanie dominacji szlachty, a z drugiej przystosować feudalną gospodarkę do wymogów nowoczesnej produkcji kapitalistycznej. Wśród obrońców starego systemu ciekawie brzmi głos Fryderyka Skarbka (Skarbek 2013, 127), umieszczony w Pamiętnikach Seglasa:

\begin{abstract}
Przybyłem do Polski z mieszaniną wyobrażeń dawnych panów i demokratów francuskich, tudzież z uprzedzeniem o srogości panów polskich i o poniżającym poddaństwie ludzi do uprawy roli przez nich używanych. Gdym się bliżej przypatrzył ciemiężycielom i uciemiężonym, nie spostrzegłem żadnych znamion ani w pierwszych okrutnych panów, ani w drugich pognębionych niewolników. [...] ci okrzyczani w Europie niewolnicy mieli częstokroć więcej sposobności dojścia do dobrego bytu i więcej pewności używania owoców pracy swojej jak wolni rolnicy mojego kraju (Skarbek 1959, 85).
\end{abstract}

Paternalizm zakłada bezwarunkową uległość chłopa i nieograniczoną władzę rodzicielską szlachcica. Podobny głos pobrzmiewa w Historii kołka w płocie Kraszewskiego, gdy narrator mówi o naturalnym przystosowaniu chłopów do znoszenia cierpienia, którego nikt inny znieść by nie był w stanie.

Głównym pomysłem na rozwiązanie kwestii agrarnej było jednak oczynszowanie. Ta forma renty zapewniała właścicielowi ziemi kapitał, opierała się jednak na przerzuceniu ryzyka na chłopa. Z powodu wysokości czynszu włościanie czasem wybierali powrót do pańszczyzny, gdy nie byli w stanie zebrać potrzebnych pieniędzy: „Oczynszowanie było imprezą szlachecka i nie chłopski pożytek miało na względzie", komentuje Śreniowski (Śreniowski 1947, 112, 114).

16 Zauważmy, że pokolenie pozytywistów podchodziło do chłopów z nieufnością, zainteresowane było raczej pomocą wysadzonym z siodła szlachcicom - zob. Rychliński 1976, 527. 


\section{Przemoc wobec chłopów w literaturze realistycznej}

(Kollokacja Józefa Korzeniowskiego - Ulana Józefa Ignacego Kraszewskiego - Wysadzony z siodła Antoniego Sygietyńskiego - Tusy Artura Gruszeckiego - Nad Niemnen Elizy Orzeszkowej)

W tej części artykułu chciałbym przedstawić obrazy przemocy stosowanej wobec chłopów, które znaleźć można w powieściach polskich powstałych w czasach, gdy pańszczyzna była coraz częściej podważana, a w końcu całkowicie zniesiona wraz z uwłaszczeniem. Te przykłady nie roszczą sobie prawa do całościowego omówienia reprezentacji pańszczyzny w literaturze polskiej dziewiętnastego wieku, a jedynie mają pozwolić na rekonstrukcję znaczeń, które w relacjach społecznych związanych z pańszczyzną rozpoznawały teksty literackie. W Kollokacji Józefa Korzeniowskiego, powieści o cyrkulacji ziemskiego majątku pomiędzy różnymi warstwami stanu szlacheckiego, nie ma właściwie miejsca dla chłopów, którzy występują wyłącznie jako policzone dusze. Chłop pojawia się tylko raz - pastuchy prezesa Zagartowskiego dokonuja prowokacji, wpuszczając świnie do ogródka Starzyckich. Dziadzio widzi „dziesiątek ogromnych świń”, które niszczą jego uprawy - szparagi i truskawki:

\footnotetext{
Wtenczas już dziadzio nie był panem siebie; rzucił „czeresznią” i jednego z nich ugodził w plecy tak silnie, że ten upadł na ziemię. Przypadł do niego starzec, zaczął go bić, szarpać za włosy i opamiętał się dopiero wtedy, gdy chłop wywrócił się na wznak, oczy w słup postawił i cały krwią się oblał. Wtenczas dziadzio odskoczył, załamał ręce, wspomniawszy na te przykrości i ambaras, jaki sprawi synowi (Korzeniowski 2003, 148).
}

Chłop zostaje ocucony i opatrzony, z dalszego przebiegu akcji dowiadujemy się, że skutki pobicia nie były dla niego groźne. Za ten akt przemocy sprawcy grozi jednak kara, sprawa kryminalna, którą wytoczy Starzyckim prezes Zagartowski. Korzeniowski umieszcza scenę w ramie, która zupełnie odwraca rzeczywiste relacje przemocy - bity chłop jest tylko elementem prowokacji złego prezesa, a faktycznymi ofiarami okazują się dziadzio i jego rodzina:

Najrozmaitsze uczucia go miotały, a ta myśl, że ściągnął taki kłopot i wrzawę na cichy i spokojny dom syna, że starą żonę, zgryzioną tym wypadkiem, wprawił w chorobę i zaprowadził do łóżka, że stał się ofiarą zimnej i wyrachowanej złości egoisty bez czucia, przyprowadzała go do rozpaczy rozdzierającej serca obecnych. Szczęściem, że tego samego wieczora przyjechała Anulka i przywiozła starcowi 
żwawego i śmiejącego się prawnuka. Złagodził się cokolwiek jego ból i sen na kilka godzin pokrzepił jego siły (Korzeniowski 2003, 149).

Literacka legitymizacja przemocy dokonuje się poprzez przedstawienie sprawcy jako ofiary. Dokładnie omówione zostają afekty dziadzia Starzyckiego, jego wściekłość, ból i rozpacz. $\mathrm{Z}$ drugiej strony, nie znamy nawet imienia tego pastuszka, nie mówiąc już o jego bólu, zupełnie jakby niczego nie odczuwał. Chłop u Korzeniowskiego oddaje swoje ciało na potrzeby pana, a zadawany mu ból jest tylko częścią tej relacji. Narracja stwarza zatem wrażenie, jakoby chłop z góry wystawiał się na przemoc, zapraszał do bicia. Prawdziwą ofiara okazuje się wtedy ten, kto te zaproszenie przyjmuje.

Bardziej rozbudowany obraz chłopów pojawia się w Ulanie Kraszewskiego. Autor Starej baśni konstruuje swoje przestawienie w ramach dyskursu antropologicznego: „i to sa ludzie; tu najszczerzej w nich może odkrywa się niczym nie krępowana natura ludzka, nagi człowiek jak wyszedł z rąk bożych, którego tylko trochę udawania nauczyli panowie, a trochę wiary duchowni” (Kraszewski 1948, 13); a wcześniej: „Jest to jeszcze stan w pół dzikiego ludu, niemyślącego o niczym nad zaspokojenie pierwszych swych potrzeb zwierzęcych" (Kraszewski 1948, 10). Kraszewski konstruuje chłopskich bohaterów jako istoty naturalne, niemal nietknięte cywilizacja, istoty, którym muszą przewodzić dwór, cerkiew i karczma, a także wiejska kultura wstydu regulująca normy obyczajowe. Złamania normy, odrzucenia wstydu dopuszcza się Ulana, żona Oxenia Honczara, uwiedziona przez Tadeusza Mrozoczyńskiego, który zakochał się w swojej poddanej i niewolnej. Co ciekawe, Ulana nie ulega przemocy fizycznej: na pytanie „Chcesz więc [...], żebym się mścił, żebym cię zmusił[...]” (Kraszewski 1948, 37), odpowiada „A cóż mi pan zrobisz? [...] każesz bić? Czyż i tak mnie nie bija? Odbierzesz chleb? - i tak go nie ma wiele - a dzieci małe w rekruty nie oddasz" (Kraszewski 1948, 37). W tej wypowiedzi ukryta jest cała przemoc wobec chłopów. Kraszewski nie przedstawia scen bicia - to widmo przemocy albo zmusza poddanych do wykonywania poleceń, albo - jak w przypadku Ulany - czyni ich już obojętnymi na przemoc. Ulana zostanie zatem uwiedziona obietnica miłości pańskiej, nie chłopskiej, ale też nie dworskiej. Co może w tej sytuacji uczynić jej mąż, postrzegany przez kochanka jak Kaliban, którego „czarna ręka gruba” wpadła pomiędzy zakochanych? Wykorzystanie Szekspirowskiej postaci zniewolonego tubylcy uruchamia oczywiste znaczenia kolonialne - Kaliban to podbity tubylec, z którego pracy korzystaja zdobywcy (zob. też interpretacje Kalibana oraz wiedźmy jako dwóch figur kapitalistycznej dominacji: Federici 2004). W tej figurze wyraża się monstrualizacja, uniezwyklenie ludzi związanych z pracą fizyczna, ludzi wyzyskiwanych, podporządkowanych. W dramacie Szekspira najważniejszym prawem, którego odmawia się temu potworowi, jest prawo do miłości, do marzenia o związku z córką pana. Kraszewski tylko trochę przesuwa akcenty - nazwanie chłopa 
Kalibanem sugeruje, że uwiedzenie jego żony będzie jej wyzwoleniem, wprowadzeniem w świat wyższej miłości i cywilizacji.

Przyjrzyjmy się formom dominacji, których doświadcza poleski Kaliban. Przede wszystkim Mrozoczyński wyznacza go do różnych zadań wymagających długiej nieobecności w domu. W tym czasie próbuje uwieść jego żonę. Kolejne wezwanie do zwiększonej pańszczyzny chłopi przyjmują z rezygnacją: utwierdzają się w przekonaniu, że „u pana dłuższe palce niż u ciebie ręce”, a sam Honczar przyznaje: „toć to ja nie pierwszy, nie ostatni, a z panem taki nie wojować". Ale to tylko pozorna rezygnacja. U chłopa rodzi się myśl o zemście: „w głosie jego przebijała stłumiona zemsta i pasowanie się bezsilnego z przemoca" (Kraszewski 1948, 79). Pamięć przemocy dworskiej administracji ma tak silna postać, że nie pojawia się nawet myśl o jakimś bezpośrednim buncie. Nawet przemoc chłopa wobec niewiernej żony, która doradzaja mu inni mieszkańcy wsi (Kraszewski 1948, 60), zostaje zahamowana przez groźbę Ulany, że za jej krzywdę sam Oxeń zginie marnie (Kraszewski 1948, 75). Wszechobecna świadomość przewagi, prze-mocy feudalnej sprawia, że jedyną możliwą formą oporu staje się podpalenie dworu, próba zabicia pary kochanków przez zdradzonego męża, która potwierdza tylko opisane we wstępie tezy autora o dzikim, naturalnym stanie chłopów, o ich potworności, braku etyki, zdominowaniu przez złe emocje. Dopełnieniem upokorzenia Honczara są różne rady udzielane mu przez innych chłopów, którzy proponują czerpanie korzyści z romansu żony. Wieś z jednej strony podlega regulacji na poziomie kultury wstydu, ale $\mathrm{z}$ drugiej wpisuje się $\mathrm{w}$ ekonomiczne pragnienie bezwzględnego pomnażania skromnego majątku, w czym honor i wstyd nie powinny przeszkadzać. Te podwójne normy jeszcze bardziej dehumanizują chłopów, którzy mieliby czerpać korzyści z utraty godności.

Wysadzony z siodła Antoniego Sygietyńskiego przedstawia degradację bohatera, szlachcica i powstańca zagubionego w Warszawie lat osiemdziesiątych, do której powrócił z Syberii. Zwykle widzimy Ernesta Załogowskiego jako ofiarę: oszustw i poniżeń - ale dwa razy autor pokazuje go także jako sprawcę przemocy: grozi on na przykład swemu adwokatowi i wymusza od niego pieniądze na własną działalność. Ale bezpośrednia przemoc stosuje wobec parobka, gdy nie radzi sobie z rachunkowymi zadaniami zarządcy majątku:

\footnotetext{
Nazajutrz wstał zły i pierwszego parobka, jaki mu się nawinął, okrutnie zlał kończugiem. Za tę sztukę, z wyroku sędziego gminnego, zapłacił chłopu pięćdziesiąt rubli za kurację i odsiedział dwa tygodnie aresztu. Ze zmartwienia, obrażony w poczuciu swej godności i dumie, która nie mogła przystać na to, aby szlachcic miał siedzieć w kozie za chłopa, rozchorował się (Sygietyński 2004, 61).
}

Zagartowski reprezentuje czasy, w których pan mógł bezkarnie używać przemocy wobec chłopów. Nowy świat, w którym nie potrafi się odnaleźć, to nie tylko rzeczywistość innych 
hierarchii opartych na statusie majątkowym, ale przede wszystkim świat nowego prawa, w którym zmienia się dystrybucja przemocy. Podobnie jak w przypadku Kollokacji pokazana tu została choroba sprawcy pobicia. Te choroby ukaranych katów ujawniaja, jak głęboko osadzone w kulturze szlacheckiej było prawo do bicia, prawo do przemocy wobec chłopów. Ograniczenie, a potem likwidacja tego prawa okazuje się dla wielu szlachciców traumą, która dotyka ich struktury afektywnej i sposobu postrzegania społecznych nierówności. Nic dziwnego, że często prowadzi do psychicznego załamania.

Przemoc nieudacznika Załogowskiego zostaje ukarana, skuteczniejsi kapitaliści znacznie lepiej radzą sobie jednak z prawnymi ograniczeniami. Powieść Artura Gruszeckiego Tusy przedstawia środowisko polskich plantatorów buraków cukrowych na Ukrainie. Ich pozycja opiera się na wielkiej własności ziemskiej, a głównym konfliktem obecnym na kartach powieści jest ich ekonomiczna rywalizacja $z$ właścicielami cukrowni. W tle rywalizacji kapitalistów, walczących o zwiększenie zysków kosztem słabszej strony, znajdują się obrazy ich relacji z chłopami i robotnikami cukrowni. Już pierwsza scena powieści przedstawia przemoc stosowana wobec chłopa w czasie polowania - chłop zostaje zbity za uderzenie pałką psa niszczącego jego żyto. Ten czyn spotyka się parę stron dalej z krytyką wielkiego plantatora, Edmunda Wireckiego. On sam, by uniknąć sprawy w sądzie, wybiera inną formę przemocy: „Gdy chłop zawinił, a kary nie pomagaja, wołam go do kancelarii i tam bez świadków staje się zadość sprawiedliwości?” (Gruszecki 1954, 22). Przemoc wobec chłopa przenosi się do miejsc zamkniętych, prywatnych, gdzie nie ma świadków. To nowy sposób na złamanie coraz bardziej „rozzuchwalonych” pracowników.

Ograniczona przemoc wobec chłopów zapewnia ich podporządkowanie rygorowi pracy, ale jednocześnie rodzi lęk. Gruszecki pokazuje to w scenie, w której główny bohater w czasie śnieżycy „Znajdował się sam z chłopem w stepie” (Gruszecki 1954, 244) - wtedy Wirecki przez moment fantazjuje o tym, że chłop mógłby go zabić i obrabować. Szybko jednak wraca do pozycji pana, by choćby dzięki przemocy słownej utrzymać własna pozycję. Wspólnie z chłopem wydobywa się z tej podwójnej opresji: zagrożenia życia (chłop odnajduje drogę, a pan prowadzi konie) oraz zagrożenia pozycji (chłop okazuje uległość, a pan zachowuje nad nim przewage).

Nową formę przemocy popańszczýnnianej przedstawia scena z zepsutą żniwiarką w Nad Niemnem. Zdarzenie zostało ujęte z perspektywy Witolda, który z oddali widzi Benedykta oraz Maksyma:

[...] postać pana Benedykta rysowała się na kształt czarnej sylwetki, wysokiej, ciężkiej, wąsatej, której rysy znikały w oddaleniu, ale ramiona dokonywały gwałtownych gestów i długie wąsy szamotały się u piersi. Naprzeciw tej sylwetki stała druga, również na tle czerwonych obłoków czarna, ale znacznie niższa, z krępymi kształtami i głową, która jeżąc się rozczochraną czupryną lękliwie wtulała się w ramiona (Orzeszkowa 2009, 286). 
Zachód słońca sprawia, że widać tylko ciemne sylwetki - jedna reprezentuje wielkość i siłę, a druga słabość. Dzięki takiej perspektywie dostrzec można istotną nierówność głównych uczestników wydarzenia, a także innych parobków stojących nieruchomo w milczeniu. Władza Korczyńskiego opiera się na przewadze fizycznej, posłuchu, pewności ruchów. A dopełnia ją bierność drugiej strony, zmuszonej do patrzenia na spektakl właściciela ziemi. $\mathrm{Na}$ razie Witold nie słyszy wypowiedzi ojca, ale nawet jego bez głosu ta scena oddaje relacje władzy i przemocy. Słowa uzupełniają ten obraz, sytuując go w ramach ekonomii. Korczyński nie tylko rzuca wyzwiska pod adresem parobka, ale przenosi całą scenę na plan relacji pracodawcy i pracownika.

A czy ty wiesz, gałganie, że ta żniwiarka więcej kosztuje, niż ty cały wart jesteś! [...]

- Czy ty myślisz - wciąż do parobka się zwracał - że ja ci to daruję? Żniwiarkę do naprawy poślę, ale co za nią w mieście zapłacę, to ci z pensji wytrącę...

$\mathrm{Na}$ te słowa chłop krępy, w siermiędze ubrany po raz pierwszy kudłatą głowę z ramion wysunął i mrukliwie przemówił:

- Nie wytrącajcie, panoczku, bo z czegóż ja z dziećmi żyć będę...

- Z głodu nie zdechniesz!... - krzyknął Benedykt. - Ordynarię masz... dach nad głową masz... krowę nawet trzymać wam pozwalam... A gdybyś zresztą i ziemię miał gryźć, wytrącę... jak Boga kocham, wytrącę... żebyś nauczył się, łajdaku, własność cudzą szanować! (Orzeszkowa 2009, 286-287).

Irytacja Korczyńskiego nie prowadzi już do bezpośredniej przemocy fizycznej, ale do nowej formy przemocy ekonomicznej - niewola ekonomiczna zastapiła dawną niewolę pańszczyźnianą: parobek żyje w zwykle „okopconych i przeludnionych” - co podkreśla Witold - czworakach, a jego praca pokrywa głównie koszty utrzymania jego rodziny. Niewielkie wynagrodzenie łatwo jeszcze pomniejszyć za pomocą systemu kar, tak popularnego w fabrykach, gdzie zarazem służył do dyscyplinowania robotników, jak i do obniżania ich płac, stwarzając dodatkowy fundusz dla właściciela. Przypomnijmy, że chłopi pańszczyźniani odrabiali pańszczyznę sprzężajną. Wraz z likwidacja pańszczyzny właściciele folwarków zostali zmuszeni do zakupu narzędzi, często także nowoczesnych, które zmniejszały koszty siły roboczej, teraz już odpłatnej. Ten kontekst nadaje dodatkowego znaczenia pouczeniu o szanowaniu cudzej własności - parobek to chłop zupełnie wywłaszczony, pozbawiony chaty, sprzętu, ziemi, pozbawiony wszelkiej własności ma szanować własność cudzą.

Słów Benedykta Orzeszkowa nie pozostawia bez odpowiedzi - ale nie może jej oczywiście udzielić chłop. Zamiast niego mówi Witold - pokazuje, jak obsługiwać żniwiarkę, 
gdzie ją szybko naprawić. To on także odbiera podziękowania parobka, który „głośnym cmoknięciem całując rękaw surduta Witolda, z uśmiechem i głośno przemówił: - Dziękuję, paniczu!” (Orzeszkowa 2009, 288). Zauważmy, że parobek mówi głośno, z uśmiechem, lecz w ten sposób może wypowiedzieć tylko swoją wdzięczność, niższość wobec dobrego pana, który umie rozmawiać z chłopami. Dopełnieniem tej sceny są rozważania o stanie chłopów. Według Benedykta są i „będą oni zawsze leniwi, niedbali i nieżyczliwi...” (Orzeszkowa 2009, 290). Witold natomiast wiąże ich kondycje intelektualna z fatalnym stanem materialnym. Jak Korczyński usprawiedliwia położenie swoich robotników - niskie zarobki, złe warunki mieszkaniowe, częste kary? „Tak krawiec kraje, jak materii staje” (Orzeszkowa 2009, 290); wcześniej mówi o „poturbowaniu nad gospodarstwem i interesami” (Orzeszkowa 2009, 189). Znowu zatem to właściciel doznaje krzywdy, to on musi radzić sobie w trudnych warunkach, na przykład obniżając płace parobkom. Benedykt w całej powieści przedstawiany jest jako ofiara - wyzyskuje go nawet żona, wpada w coraz większe kłopoty ekonomiczne, po to tylko, by utrzymać polskie gospodarstwo, nie dopuścić do sprzedaży ziemi Rosjanom. W scenie ze żniwiarką widzimy drugą stronę tego patriotycznego gospodarstwa - wyzyskiwanych i poniżanych parobków.

Pięć omówionych przykładów literackich pokazuje, jak literatura realistyczna zawsze obok, na marginesach głównych tematów przedstawienia - ujmuje różne formy przemocy wobec chłopów. Ciagłe trwanie zarówno przemocy fizycznej i słownej, jak też innych form poniżenia pozwala panom na utrzymanie nad chłopami przewagi, która opiera się nie tylko na własności środków produkcji, ale i na tłumieniu potencjalnego buntu przez ucisk i upokorzenie.

\section{Przemoc pańszczyźniana w literaturze ludowej}

Jednym z fundamentów przemocy pańszczyźnianej było odcięcie chłopów od edukacji utrzymywani w analfabetyzmie poddani nie mieli oczywiście dostępu do twórczości literackiej, trudno zatem liczyć na obszerne literackie źródła tworzone przez samych chłopów. Spisywana przez miłośników i badaczy kultury ludowej tradycja ustna podlegała cenzurze na poziomie zapisu, co dodatkowo ogranicza dostęp do tego typu tekstów ${ }^{17}$. Relacje o pańszczyźnie znaleźć możemy głównie w pamiętnikach, wspomnieniach, czasem w piosenkach albo wierszach, często pisanych już po uwłaszczeniu. To przede wszystkim wspomnienia dotyczące wymuszania pracy poprzez bicie oraz bólu i chorób spowodowanych przemoca.

\footnotetext{
${ }^{17}$ Czernik wspomina ,liberalizm” Kolberga oraz cenzurę Glogera, który uznawał wiersze o pańszczyźnie za niemoralne. Zob. Czernik 1951, 62.
} 
Dominik Piękoś w utworze $Z$ lat męczeństwa ludu (na tle podania ludowego) konstruuje postać pana, młodego dziedzica, który powtarza pytanie „Co to za bieda?”. Nie mogąc uzyskać zadowalającej odpowiedzi, stosuje przemoc wobec swojej służby - bije i wypędza z dworu. Dzięki młodzieńcowi, który zaprasza go do chłopskiej chaty, a potem przemienia na chwilę w chłopa, nie tylko poznaje on biedę, ale doświadcza jej, dosłownie, na własnej skórze. Budzi się w chacie, w chłopskiej sukmanie i zostaje wezwany do odrabiania pańszczyzny: popychany „Na ekonoma rzuca się kaleczy”, za co grozi mu kara śmierci. W tej krótkiej historii bicie pojawia się kilka razy, a jednym z najczęściej chyba występujących wyrazów jest „kańczug”. Bicie to kara za spóźnienie, za złe wykonywanie pracy. Służba dworska także może stać się ofiarą przemocy, gdy nie potrafi odpowiedzieć na pytanie o biedę. Przemiana pana w chłopa następuje po ciosie wymierzonym przez młodzieńca, jakby bicie było jedyna formą kontaktu, komunikacji, znacznie skuteczniejszą niż słowo. Świat przeniknięty przemocą należy już jednak do przeszłości:

Bo tu na ziemi w czasy pańszczyźniane

Na wszystko były w odpowiedzi baty;

I szedł tak we łzach lud poniewierany,

A za nim gnały z kańczugami katy! (Piękoś 1947, 134)

Popularny motyw przemiany dostojnika w nędzarza służy do pokazania fenomenologii wszechobecnej przemocy. W licznych relacjach wspomina się o ciagnięciu za włosy ${ }^{18}$, rozciaganiu, chorobach i śmierci wskutek pobicia (Czernik 1951, 67). Przemoc pańszczyźniana najczęściej miała jednak formę widowiska, w którym brać udział musiała cała grupa chłopów. Przeanalizujmy dwa przykłady:

\begin{abstract}
Zdarzyło się, że dwaj ludzie, gospodarze pańszczyźniani ze wsi Wola Pogroszewska, młodzi, żonaci i dzietni, w nocy o żniwach w 1863 r. wzięli po kilka snopków zboża z pola dworskiego i przenieśli do swoich stodół. To się wydało, dziedzic zwołał gromadę i tak oskarżonym powiedział: „Teraz polskie prawo, a ono jest takie: kto ukradł i został złapany, będzie wisiał, skazuję was obu na szubienicę, karbowy daj postronki”. Gromada struchlała, osądzeni, ich żony z małymi dziećmi rzucili się z lamentem na ziemię, zaczęli prosić, błagać o zmiłowanie, pan nie ustępował. Wtedy najstarsi ludzie - gospodarze dwóch wiosek, pomiędzy nimi mój wychowawca - Karol Jóźwiak, już wtedy powszechnie szanowani, uklękli przed dziedzicem na kolanach,
\end{abstract}

\footnotetext{
${ }^{18}$ Kazimierz Deczyński wspomina pobicie swojego ojca, gdy odmówił on wykonania dodatkowej pracy, zob. Deczyński 1978, 106.
} 
poczołgali się do jego stóp i te stopy całując, błagali: „Wielmożny panie! dla ich żon, dla dzieci małych, co sierotami zostaną, daruj im panie życie!”

To pomogło. Obwinieni zostali obnażeni do pasa, musieli wziąć na plecy po snopie zboża i byli wobec całej gromady prowadzeni na postronkach, którymi powiązano im ręce; następnie byli kładzeni pod każdym z trzech krzyżów, które stały na drodze, pomiędzy wsiami Wola Pogroszewska, a Głudną i dostali na gołe ciało pod każdym krzyżem po 50 razów - razem po 150. Dwóch karbowych biło, a pan pilnował i wołał: „lepiej bijcie, bo wy będziecie bici”, to też pod trzecim krzyżem całe ciała tych ludzi były od nóg poprzez pośladki tak zbite, że krew została na ziemi, a bici już sami wstać nie mogli. Podniesiono ich i musieli na klęczkach ucałować pańskie nogi w podzięce za darowanie im kary śmierci (Nocznicki 1947, 16-17).

Mimo że sama scena nie wiąże się bezpośrednio z przymusem pracy, a z kara za kradzież, świetnie ilustruje związaną z pańszczyzną rytualizację przemocy. Kradzieży dokonuje dwóch gospodarzy, ale w scenie bierze udział cała gromada: od najstarszych po małe dzieci. Właśnie ci najbardziej szanowani przedstawiciele wsi muszą się upokorzyć, czołgać, całować po rękach, błagać, żeby kara śmierci została zamieniona na kaźń. Zorganizowanie procesji, katowanie chłopów przy trzech krzyżach naznacza przemoca całą przestrzeń wsi, a jednocześnie sakralizuje tę przemoc, łącząc ją z porządkiem religijnym. Nocznicki wyraźnie podkreśla, że scena ma miejsce w 1863 roku, w czasie powstania styczniowego, a pan powołuje się na „polskie prawo” - demonstracja „polskiej sprawiedliwości” i „polskiej władzy" uczyniła ,nawet na tych zwyczajnych bicia ludziach piorunujące wrażenie” (Nocznicki 1947, 17). Chłopskie wspomnienia wielokrotnie podkreślają to skojarzenie polskiej władzy z przemoca, tłumacząc częsty dystans chłopów do walk niepodległościowych.

Kim są chłopi, którzy przeszli taką mękę? Nocznicki wspomina, że znał ich jako bardzo pracowitych gospodarzy. Wiadomo zatem, że przeżyli i wrócili do pracy. Trudno sobie wyobrazić, jakie konsekwencje dla ich psychiki miało to doświadczenie przemocy. Skazanie na śmierć właściwie wyłącza ich już ze wspólnoty żywych, zamiana wyroku na karę fizyczna także lokuje ich ciała na granicy śmierci. Ale przede wszystkim ma ona zabić nie tyle ich samych, co tkwiąca w nich możliwość nieposłuszeństwa. Przesadna kara nie tyle ma stworzyć podmioty, które - jak niewolnik w modelu Hegla - nie wytrzymały lęku przed śmiercią, co anulować chwilowe upodmiotowienie i stworzyć żywe ciała z martwą psychika, niezdolne do buntu i sprzeciwu.

W dalszych fragmentach Nocznicki, wychowany w samodzielnym gospodarstwie ojczyma, wspomina swoja pracę na dworze, gdzie był na tzw. „posyłce”. Mimo że dawno już minęły czasy pańszczyzny, dwór to miejsce, w którym spotyka się z pogarda, poniżeniem I wyzyskiem. Wytrzymuje tam tylko półtora roku, by później szukać szans gdzie indziej. 
W artykule Dawniej a teraz Wincenty Witos przytacza opowiadanie o 1846 roku, już po rabacji. Wśród chłopów rozchodzi się informacja, że decyzją cesarza pańszczyzna ustała. Po naradzie postanawiają nie podejmować wcześniej ustalonych prac, przepędzają także ze wsi dworskich urzędników. To chwilowe zwycięstwo chłopów: „Wieś tryumfowała, uciechom nie było końca, ściskano się i całowano z radości. W dwóch karczmach we wsi się znajdujących cała wieś zgromadzona ucztowała co się zowie" (Witos 1947, 197). Następnego dnia przybywa jednak wojsko, by stłumić bunt:

Kiedy spędzono wszystkich, zatrzaśnięto bramy dworskie, wyniesiono ławy, żołnierze utworzyli szpaler, pachołcy dworscy stanęli z rózgami. Chłopi pospuszczali głowy na same piersi, wzdychając ciężko, kobiety krzyczały w niebogłosy, jękiem rozrywającym serce. Widok tych nędzarzy wodzących błędnymi oczyma mógł kamień poruszyć, nie poruszył ludzi jednak. Nie poruszył tych, co serce już dawno zatracili.

Obecny przy egzekucji ks. proboszcz, któremu nawiasem mówiąc, także się jego „pańszczyźniacy” zbuntowali, wypowiedział gorące kazanie o zbuntowanych swego czasu w niebie aniołach i o karze jak ich dotknęła, kończąc wezwanie do cierpliwego zniesienia zasłużonej kary i ofiarowania jej za ten straszny grzech, jakiego się dopuścili. W zgromadzeniu zrobiło się wielkie poruszenie, jedni błagają litości i przebaczenia, inni zgrzytają ze złości bezsilnej zębami.

Egzekucja się zaczyna. Starego Grzegorza położono pierwszego przemocą na ławie, w obnażone ciało wyliczono 50 plag ciężkich, a za każdym razem powtarzało się pytanie rządcy „Będziesz robił pańszczyznę, nie będziesz się buntował?” Chłop milczy, zęby zaciął, nic nie odrzekł, jęku nie wydał. Bijąc dalej, czekając skutku nie doczekali się.

Kolejno wszyscy otrzymali swoje, jedni mniej, drudzy więcej plag, stosownie do rozkazu pana rządcy. Parę kobiet, nie mogąc wytrzymać bólu od kijów po gołym ciele, zrobiły naturalne potrzeby. Zmęczonych pachołków zastąpiono coraz innymi, nowe siły pracowały (Witos 1947, 198).

Scenariusz przemocy ma swój porządek - zaczyna się od przemocy żołnierzy, którzy wywlekają chłopów ze wsi, by zapędzić ich na „plac egzekucji do dworu”. Służba dworska ustawia tam ławy, na których zostaną rozciagnięci zbuntowani chłopi. W przedstawieniu bierze udział jeszcze ksiądz, który uzupełnia przemoc fizyczną umoralniającą przemową. Proboszcz interesuje się stłumieniem buntu osobiście, gdyż jego chłopi też odmówili pracy. Po jednej stronie przemocy znajduje się zatem dwór, ksiądz i wojsko (czyli państwo). Po drugiej chłopi - zmuszeni do kierowania w stronę oprawców upokarzających próśb o złagodzenie kary, która i tak zostanie wykonana. Tylko niektórym udaje się wytrzymać 
bicie, wytrwać w milczącym sprzeciwie. Większości pozostaje zwierzęcy jęk. Bicie przywraca porządek, chłopi wracają do pracy:

Ludzie chodzili jak mary nie zważając ani na krzyki i przekleństwa, gęsto przez polowych sypane, ani na drwiny bezlitosne, ani też na razy spadające coraz częściej na plecy, odziane brudną zgrzebną koszuliną. Z ócz tylko dobywały się gorace łzy, które ocierano ukradkiem, i ciężki jęk ze zbolałej duszy. Dokazano swego, ubezwładniono ciało, złamano i zabito ducha, nastapiło odrętwienie i obojętność na wszystko (Witos 1947, 199).

Podporządkowanie polega na zbliżeniu podporządkowywanego do śmierci - przez tortury, głód, bicie, poniżenie - ale pozostawienie przy życiu. Dlatego bunt świetnie wpisuje się w dialektykę podporządkowania, bo stłumiony opór wytwarza słaba podmiotowość, kogoś kto przegrał walkę ze śmiercią, przeżył jej bliskość - i stracił swoje nadzieje.

Jan Philipp Reemstma zauważa, że „Celem przemocy - lokującej, raptywnej, autotelicznej - jest ciało, przemoc ekstremalna redukuje ofiarę do jej cielesności” (Reemstma 117) - w tym przypadku celem jest sprowadzenie jednostek do bezwolnych ciał pokornie wykonujących pracę, nie podejmujących żadnej własnej inicjatywy. Następstwa tego zbiorowego bicia trwaja przez długi czas. Gdy pańszczyzna naprawdę zostanie zniesiona, chłopi nie będa potrafili się z tego cieszyć, obawiając się jej powrotu. Pańszczyzna trwa zatem jako widmo, które zawsze może się odrodzić.

Najszerzej konsekwencje pańszczyzny omawia inny działacz ludowy, a także pisarz i publicysta, Jakub Bojko w artykule Dwie dusze. Za pomoca pojęcia drugiej duszy Bojko opisuje wielopokoleniowe trwanie traumy pańszczyzny, która oddziałuje także na jednostki urodzone już po zniesieniu pracy przymusowej. Groza pańszczyzny zamienia się zatem w niewolniczego ducha, który pęta ciała i umysły potomków chłopów:

W nas pokutuje dusza bardzo starej brzydkiej pani, która zmarła w roku pańskim 1848, a zwała się pańszczyzna. Pani ta trzymała w niewoli strasznej przeszło 400 lat całe nasze chamskie plemię i zabiła w chłopie człowieka, z zrobiła po prostu gnat, maszynę, z którą można było zrobić, co ta pani chciała (Bojko 2002, 21).

Przytoczmy także obraz następstw pańszczyzny nakreślony przez Witosa:

Chłop nie czuł swojej godności: zapomniał o tym, że tak samo jak pan dziedzic jest stworzony na obraz i podobieństwo boskie, i że grzeszy, poniżając swoja godność i oddając innym ludziom cześć Bogu należną. Słowem, lud była to wielka, gruba, potężna masa, zginająca się jednak w kabłąk przed dziesiętnikiem lub pachołkiem 
pańskim. Ciemny, głupi, pokorny, uległy aż do podłości, stawał się jednak strasznym, mianowicie, gdy coś słyszał o Polsce (Witos 1947a, 202).

Konsekwencją rytuału przemocy, w którym uczestniczyć musiała cała chłopska gromada, jak też każdy chłop z osobna - w podwójnej funkcji ofiary: raz jako bita osoba, raz jako widz, który widział poniżenie swoich bliskich, sąsiadów - jest przede wszystkim określona struktura afektywna, która wynika z naruszenia poczucia dumy i godności, a w której mocno usadowiły się lęk i wstyd, uległość i bierność. Skrajna przemoc nie rodzi już buntu, oporu, ale raczej likwiduje podmiotowość, sprawia, że o żadnym sprzeciwie się już nie myśli, bezrefleksyjnie wykonując każde polecenie. Bojko przedstawia trwanie duszy pańszczyźnianej na przykładzie chłopskich dzieci, którym udało się wyrwać ze wsi i zrobić karierę księdza, urzędnika czy nauczyciela. Ich postawy opierają się często na odcięciu od chłopskiego pochodzenia i przyjęciu perspektywy innych grup społecznych, wobec których znajdują się w relacji podporządkowania. Dusza „pańszczyźniana robi z ciebie cielę, bałwana, który wtedy gnie się w pas jak niewolnik” (Bojko 2002, 23). Nie można jednak zapominać, że wiele z tych stanowisk, na które awansowała część „dusz pańszczyźnianych”, wymagało akceptacji bardzo podobnych form poniżenia i poddaństwa jak pozycja chłopa. Być może zatem równie ważnym czynnikiem trwania duszy pańszczyźnianej była nie tylko przekazywana mentalność, ale też struktura relacji społecznych, w której ktoś musiał zaakceptować swoja pozycję niewolnika czy sługi.

\title{
Zakończenie
}

Wolfgang Sofsky zauważył, że

\begin{abstract}
Żaden język nie ma tak wielkiej siły przekonywania jak język przemocy. Nie wymaga on tłumaczenia i nie pozostawia otwartych kwestii. W żadnym innym przypadku władza nie jest skuteczniejsza, bardziej rzeczywista. Żadne inne działanie nie ukazuje w sposób bardziej drastyczny przewagi pana nad parobkiem (Sofsky 1999, 19).
\end{abstract}

Przemoc posiada charakter antyhermeneutyczny. Nie tyle chodzi o to, że język nie wymaga tłumaczenia, co o próbę wyrwania podmiotów z języka. Czyż nie jest tak, że język przemocy właśnie domagał się tłumaczenia, hermeneutyki, próby wypowiedzenia tego doświadczenia przez kolejne pokolenia? Ale zawsze to tłumaczenie, jako poezja chłopskiego buntu, musiało być blokowane, tłumione przez panów. Już w Żeńcach Szymona Szymonowica dialog dwóch bohaterek pełen skarg na uciążliwą pracę zostaje przerwany, gdy tylko pojawia się nadzorca. „I teraz mu zaśpiewam, acz mi nie wesoło; / Niesmaczno ida pieśni, gdy się poci czoło!” (Szymonowic 2000, 164), mówi Pietrucha i śpiewa pieśń o słoneczku - przechodząca w kpiny 
ze starosty, gdy ten się oddala. Szymonowic zapisuje tu podwójna pieśń ludu - pierwsza, mówiona skrycie, i druga, przeznaczona dla nadzorcy - sielanka dotycząca słońca. Niestety, przetrwała przede wszystkim ta druga pieśń, chętnie zapisywana w dziewiętnastym wieku, bo pasowała do romantycznego obrazu szczęśliwej pracy chłopów, a z czasem i część chłopów zapragnęła zobaczyć siebie w tym obrazie: niestrudzonych, bliskich ziemi i przyrody ludzi prawdziwej pracy, dalekich od pozorów i sztuczności miast (tak Stanisław Pigoń opisywał „chłopski stanowy ideał człowieczeństwa”, zob. Pigoń 1983, 114). Różne narracje obecne w kulturze chłopskiej - z jednej strony o pracy, z drugiej o buncie - zostały w systemie feudalnym potraktowane w zupełnie inny sposób. Jak zauważa Wasiewicz, wartości związane z pracą i pobożnościa były „wzmacniane i propagowane, podczas gdy te pierwsze [związane z buntem i oporem - przyp. PT] piętnowano, ukazując je jako antywartości czy też wady a dokładniej: grzechy samowoli, butności, krnąbrności, pychy itp.” (Wasiewicz 2014, 153). Pierwsza pieśń, pieśń o buncie, a przede wszystkim pieśń o przemocy - ja pisze Czernik - nie mogła zostać w pełni wypowiedziana. Charakterystyczna dla czasów pańszczyzny wszechobecna przemoc fizyczna nie tylko bezpośrednio zmuszała do pracy, ale przede wszystkim likwidowała wspólnotę jako wartość kulturową komunikacyjną i polityczna, wspólnotę mowy i rozmowy, zaufania i nadziei. Dopiero złożone teorie sfery publicznej i genezy nowożytnego kapitalizmu potrafią skonstruować perspektywę umożliwiająca ujęcie kultury klas podporządkowanych, która ani nie jest kultura pierwotnego ludu (ewentualnie dzikim ludem bez kultury), ani nie dysponuje jakąś autonomiczną historia, lecz nierozerwalnie wiążę się ze stłumieniem (Habermas), blokadą (Kluge, Negt), wywłaszczeniem własnego dziedzictwa kulturowego i utratą instytucji (Polanyi, Buck-Morss).

Dziewiętnasty wiek często przedstawia się jako wiek nowoczesności, rewolucji, kapitału i burżuazji - czas, w którym feudalne relacje społeczne i ekonomiczne należały już do przeszłości, odzywającej się czasem jeszcze pod postacią przeżytków i pozostałości. Ten obraz ukrywa inną stronę ówczesnej rzeczywistości. Nawet pobieżna znajomość literatury i kultury dziewiętnastego wieku pozwala zauważyć nadmierna obecności owych przeżytków - ujawniających się choćby w funkcji, jaką w europejskiej literaturze pełnią arystokratyczne tytuły czy posiadłości ziemskie. Arno J. Mayer zwrócił uwage, że te relikty były nie tylko obecne, ale też żywe (Mayer 1984, 28), a tradycyjne ziemiaństwo przystosowało się do kapitalizmu (Mayer 1984, 37). „Aktywnej symbiozie” (Schumpeter 2009, 168) ziemiaństwa i burżuazji, w której nowe elity odgrywały zdominowaną rolę, odpowiadał równie skomplikowany proces przemian sił roboczych: zniesienie poddaństwa i pańszczyzny nie oznaczało przecież automatycznego stworzenia rynku wolnej siły roboczej, lecz osadzało robotników - zarówno rolnych, jak i przemysłowych - w amalgamacie różnych form przemocy zmuszających ich do podjęcia pracy i poddania się nowym modelom wyzysku. Analogicznie do sformułowania Schumpetera, użytego w odniesieniu do siły roboczej 
dziewiętnastego wieku, można mówić o „pasywnej symbiozie” starych i nowych form przymusu pracy, które miały wytworzyć efekt bierności, braku oporu u nowych robotników i uczynić z nich zależnych oraz podporządkowanych parobków wielkich folwarków i fabryk ${ }^{19}$. Przemoc pańszczyźniana do dziś nie znajduje języka, który byłby zdolny wyrazić jej charakter. Zupełnie jakby dalej istniał jakiś zakaz mówienia, tłumaczenia, powracania do krzywd - zakaz oparty jednocześnie na wstydzie i lekceważeniu, a może po prostu trudności w znalezieniu kodu do wyrażenia tak nieheroicznych traum jak posiadanie statusu poddanego chłopa. Społeczeństwo pańszczyzny przenikał podwójny lęk - chłopi, którzy doznawali przemocy, a szczególnie przemocy jako odpowiedzi na ich roszczenia i bunty, musieli żyć z pamięcią o okrucieństwach, które mogły powrócić. Ale lęk przenikał także środowisko panów feudalnych, nawiedzanych przez widmo buntu poddanych, który stanowił podwójne zagrożenie grup uprzywilejowanych - fizyczne, jako zagrożenie gwałtem, przemoca, śmiercią, ale też ekonomiczne - jako zagrożenie utraty majątków zapewniających zwykle wygodne I bezpieczne życie rentiera. Oczywiście ten złożony lęk nie znika razem z pańszczyzną. Przeciwnie, kapitalizm dziewiętnastego wieku wydaje się go wzmacniać (cierpi na niego bohater powieści Edwarda Bellamy'ego W roku 2000, żyjący w arcynowoczesnej przestrzeni Stanów Zjednoczonych). W każdym kolejnym etapie kapitalizmu dokonuje się inna dystrybucja przemocy i lęku. Dusza pańszczyźniana trwa długo po zniesieniu pańszczyzny nie tylko z powodu kulturowej pamięci traumy, ale przede wszystkim dlatego, że nowe warunki pracy i relacji społecznych (np. w odniesieniu do parobków) niewiele różnią się od tych, które pozornie udało się zlikwidować w połowie dziewiętnastego wieku.

Dyskusje z czasów powstania listopadowego (Meloch 1939) pokazują na przykład jasno, że sprzeciw wobec pańszczyzny miał co najmniej podwójny charakter. Pod ideologicznym uzasadnieniem zbudowanym na odrzuceniu nieludzkiego poniżenia krył się bowiem argument ekonomiczny - o nieefektywnym charakterze pracy przymusowej w porównaniu do pracy wolnego chłopa płacącego czynsz. Wiele wyliczeń, a także faktycznych świadectw odnoszących się do sytuacji chłopów, którzy powracali do pańszczyzny, gdyż nie byli w stanie zapłacić wysokich czynszów, pokazuje, że oczynszowanie często pogarszało i tak już fatalną sytuację chłopów.

Przypuszczam, że tę sytuację można potraktować jako model dziewiętnastowiecznych emancypacji. Mimo że odwołują się do haseł humanizmu, wolności I równości, ich pozytywny, wyzwalający charakter odczuwalny jest głównie przez przedstawicieli klas uprzywilejowanych (a przynajmniej ich „postępowej” części), którzy widzą w nich nową formę organizacji siły roboczej i wyzysku. Klasy podporządkowane

\footnotetext{
19 Proces podporządkowania sił roboczych nowym formom pracy rozpoczyna się znacznie wcześniej, wraz z powstaniem manufaktury. Na temat problemu sił roboczych w polskich manufakturach zob. Assorodobraj 1946. Globalny kontekst przemian sił roboczych w osiemnastym wieku opisuje m.in. Buck-Morss 2014.
} 
zostaja natomiast uwolnione z jednego systemu przymusu, by zaraz odnaleźć się w nowym, opresywnym w inny sposób.

Nie chciałbym, by ta argumentacja została potraktowana jako obrona pańszczyzny czy jako jakaś konserwatywna retroutopia. Wydaje mi się jednak, że nie ma żadnych szans na przedstawienie rzeczywistej historii dziewiętnastego wieku w ramach narracji modernizacyjnej czy liberalnej, której elementy znalazły się także w wielu - szczególnie dotkniętych pozytywizmem - wersjach marksizmu. Jeżeli patrzymy na historię zniesienia pańszczyzny jako na epizod z historii subsumpcji sił roboczych pod kapitał, przedstawienie historyczne musi wyglądać zupełnie inaczej. I nie chodzi tu o to, że postęp ma swoją cenę i swoje ofiary. Raczej o to, że celem tego postępu jest właśnie utrzymanie ofiar w tych samych pozycjach, z których próbuja się wyrwać. Postęp i emancypacja w dziewiętnastym wieku są zatem dziejowym złudzeniem, któremu czasem ulegają klasy podporządkowane - przyznając tym samych kluczowym hasłom zupełnie inne znaczenia: w odniesieniu do likwidacji pańszczyzny widać to $\mathrm{w}$ dążeniach do zachowania pozycji przez klasy uprzywilejowane (dzięki czynszom) i w chłopskich nadziejach na własność gruntowa. Nawet po prawdziwym uwłaszczeniu to marzenie spełniło się inaczej, niż oczekiwano - chłopi musieli płacić duże podatki, zwiększył się proletariat rolny, a pozycja parobków niewiele różniła się w kwestii położenia egzystencjalnego od pańszczýnnianych chłopów. Jedyną szansą na poprawę własnej pozycji wydawała się czasowa bądź stała emigracja do miast (ewentualnie wsi europejskich i amerykańskich) i próba zgromadzenia własnego kapitału, czyli dołączenia do społeczności posiadaczy własności. Ale to mogło się udać tylko niewielu. 


\section{Wykaz literatury}

Assorodobraj, Nina. 1946. Poczatki klasy robotniczej. Problem rak roboczych w pržemyśle polskim epoki stanisławowskiej. Warszawa: Czytelnik.

Bojko, Jakub. 2002. Gorqce stowa. Wybórpism. Wybór, wstęp i oprac. Franciszek Ziejka. Kraków: Universitas.

Buck-Morss, Susan. 2014. Hegel, Haiti i historia uniwersalna. Tłum. Katarzyna Bojarska. Warszawa: Wydawnictwo Krytyki Politycznej.

Burszta, Józef. 1985. Chłopskie źródła kultury. Warszawa: Ludowa Spółdzielnia Wydawnicza.

Cerman, Markus. 2012. Villagers and Lords in Eastern Europe, 1300-1800. Palgrave Macmillan: Basingstoke.

Czernik, Stanisław. 1951. Poezja chłopów polskich. Pieśn ludowa w okresie pańsžçyźnianym. Warszawa: Ludowa Spółdzielnia Wydawnicza.

Czernik, Stanisław i Julian Przyboś. 1955. Wrięli diabli pana. Antologia poezji walczqcej o postęp $i$ wyzwolenie społeczne 1543-1953. Oprac. Stanisław Czernik i Julian Przyboś. Warszawa: Ludowa Spółdzielnia Wydawnicza.

Schwab, Dieter. 1975. „Eigentum”. W Geschichtliche Grundbegriffe: Historisches Lexikon zur politisch-sozialen Sprache in Deutschland. T. 2. Red. Reinhart Koselleck. Stuttgart: KlettCotta.

Deczyński, Kazimierz. 1978. Pamiętnik chłopa nauczyciela. Wstęp i przypisy Krzysztof Groniowski. Warszawa: Ludowa Spółdzielnia Wydawnicza.

Federici, Silvia. 2004. Caliban and the Witch: Women, the Body and Primitive Accumulation. New York: Autonomedia.

Franko, Iwan. 1979. O literaturze polskiej. Wyboru dokonał i opracował Mikołaj Kuplowski. Kraków: Wydawnictwo Literackie.

Gerstenberger, Heide. 2017. Markt und Gewalt. Die Funktionsweise des historischen Kapitalismus. Münster: Westfälisches Dampfboot.

Gruszecki, Artur. 1954. Tuzy. Wydawnictwo Literackie: Kraków.

Grynwaser, Hipolit. 1951. Pisma. T. 2. Kwestia agrarna i ruch wtościan w Królestwie Polskim w pierwszej potowie XIX wieku: 1807-1860. Studium archiwalne. Praywódcy i burzyciele wtościan. Wrocław: Wydawnictwo Zakładu Narodowego im. Ossolińskich.

Bojko, Jakub. 1947. „Z chłopskich doświadczeń i rozmyślań”. W Wybór pisaray ludowych. T. I. Oprac. Stanisław Pigoń. Wrocław: Ossolineum.

Kant, Immanuel. 2011. Metafiaykea moralności. W Immanuel Kant. Drieła zebrane. T. V. Red. Wojciech Włoch. Touń: Wydawnictwo Naukowe Uniwersytetu Mikołaja Kopernika.

Kieniewicz, Stefan. 1953. Sprawa włościanska w powstaniu styczniowym. Wrocław: Zakład Narodowy im. Ossolińskich.

Kochanowicz, Jacek. 1981. Pańsz̧çyżniane gospodarstwo chtopskie w Królestwie Polskim w I połowie XIX $w$. Warszawa: Uniwersytet Warszawski. Wydział Nauk Ekonomicznych.

Kochanowicz, Jacek. 1992. Spór o teorie gospodarki chtopskiej. Gospodarstwo chtopskie w teorii ekonomii i w historii gospodarczej. Warszawa: Wydawnictwa Uniwersytetu Warszawskiego.

Korzeniowski, Józef. 2003. Kollokacja. Kraków: Universitas. 
Kowalewski, Krzysztof. 2014. „Pańszczyzna i poddaństwo w Europie Środkowej - stan badań”. W Drogi odrębne, drogi wspólne. Problem specyfiki roz̧woju historycz̨nego Europy Środkowo-W schodniej w XIX-XX wieku. Red. Maciej Janowski. Warszawa: Instytut Historii Polskiej Akademii Nauk.

Koźmian, Kajetan. 2000. Ziemiaństwo polskie, rękopiśmienna wersja poematu w pięciu pieśniach. Tekst odnalazł, oprac., uwagami wstępnymi oraz komentarzem historycznoliterackim opatrzył Piotr Żbikowski; skolacjonowanie tekstu, objaśnienia rzeczowe, filologiczne i historyczne Marek Nalepa. Kraków: Collegium Columbinum.

Kraszewski, Józef Ignacy. 1948. Ulana. Powieść poleska. Objaśnieniami i posłowiem opatrzył Wiktor Hahn. Łódź-Wrocław: Wydawnictwo Władysława Bąka.

Kuligowski, Waldemar. 2016. „Chamska historia Polski. Tezy i antytezy”. Czas Kultury 3. Leder, Andrzej. 2016. „Nienapisana epopeja”. Teksty Drugie 6.

Leskiewiczowa, Janina. Red. 1964. Zarys historï gospodarstwa wiejskiego w Polsce. T. 2. Warszawa: Państwowe Wydawnictwo Rolnicze i Leśne.

Locke, John. 1992. Dwa traktaty o rzadzie. Tłum. Zbigniew Rau. Warszawa: PWN.

Mayer, Arno J. 1984. Adelsmacht und Bürgertum. Die Krise der europäischen Gesellschaft 1848-1914. Tłum. Karl Heinz Siber. München: Beck.

Nocznicki, Tomasz. 1947. Moje wspomnienia z ubiegtego sycia. Warszawa: nakł. Stronnictwa Ludowego.

Nocznicki, Tomasz. 1965. Wybór pism. Wyboru dokonał i wstępem opatrzył Henryk Syska. Warszawa: Ludowa Spółdzielnia Wydawnicza

Orzeszkowa, Eliza. 2009. Nad Niemnem. Oprac. Józef Bachórz. Wrocław: Ossolineum.

Piękoś, Dominik. 1947. „Z lat męczeństwa ludu (na tle podania ludowego)”. W Wybór pisarayy ludowych. T. II. Oprac. Stanisław Pigoń. Wrocław: Ossolineum.

Pigoń, Stanisław. 1974. Na drogach kultury ludowej. Roaprawy i studia. Wyb. i oprac. Tomasz Jodełka-Burzecki. Warszawa: Ludowa Spółdzielnia Wydawnicza.

Pigoń, Stanisław. 1983. Z Komborni w swiat. Wspomnienia młodości. Warszawa: Ludowa Spółdzielnia Wydawnicza.

Piszczkowski, Mieczysław. Oprac. i wstęp. 1972. Wieśpańsz̨zyźniana w literaturže polskiej (w. XV-XIX). Warszawa: Ludowa Spółdzielnia Wydawnicza.

Polanyi, Karl. 2010. Wielka transformacja. Polityczne i ekonomicz̨e źródła naşych çasów. Tłum. Maria Zawadzka. Warszawa: PWN.

Rauszer, Michał. 2016. „Buntów chłopskich nie było. Pańszczyzna i opór”. Czas Kultury 3: 90-99.

Reemtsma, Jan Philipp. 2011. Zaufanie i przemoc: esej o szczególnej konstelacji nowoczesności. Tłum. Magdalena Kałużna, Izabela Sellmer, Katarzyna Śliwińska. Poznań: Wydawnictwo Poznańskie.

Rychliński, Stanisław. 1976. Wybór pism. Wyboru dokonał i wstępem opatrzył Przemysław Wójcik. Warszawa: PWN.

Schumpeter, Joseph A. 2009. Kapitalizm, socjalizm, demokracja. Tłum. Michał Rusiński. Warszawa: PWN. 
Sismondi, Jean Charles Léonard Simonde de. 1955. Nowe rasady ekonomii politycznej czyli o bogactwie i jego stosunku do ludności. T. I-II. Tłum. Witold Giełżyński. Warszawa: PWN.

Skarbek, Fryderyk. 2013. Gospodarstwo narodowe. Wybór pism. Wyboru dokonal, wstępem i przypisami opatrzył Piotr Szymaniec. Kraków: Ośrodek Myśli Politycznej.

Sofsky, Wolfgang. 1999. Traktat o przemocy. Tłum. Marek Adamski. Wrocław: Wydawnictwo Dolnośląskie.

Stankiewicz, Zbigniew. 1968. „Okres reform uwłaszczeniowych”. W Z driejów chtopów polskich (od wczesnego feudalizmu do 1939 r.). Warszawa: Ludowa Spółdzielnia Wydawnicza.

Staszic, Stanisław. 1954. „O statystyce Polski”. W Stanisław Staszic. Pisma filozoficzne $i$ spoleczne. Red. Bogdan Suchodolski. Warszawa: PWN.

Sygietyński, Antoni. 2004. Wysadzony z siodta. Kraków: Universitas.

Szymonowic, Szymon. 2000. Sielanki i pozostałe wiersze polskie. Oprac. Janusz Pelc. Wrocław: Zakład Narodowy im. Ossolińskich.

Śreniowski, Stanisław. 1947. Drieje chłopów w Polsce. Szkice o ustroju społecznym. Warszawa: Czytelnik.

Topolski, Jerzy. 1982. „Modele teoretyczne i historyczne w interpretacji rozwoju feudalizmu w Europie Wschodniej (X-XVIII wieku)". W Jerzy Topolski. Prawda i model w historiografii. Lódź: Wydawnictwo Lódzkie.

Wasiewicz, Jan. 2014. „Bunty chłopskie”. W Polskie miejsca pamięci. Drieje toposu wolności. Red. Stefan Bednarek, Bartosz Korzeniewski. Warszawa: Narodowe Centrum Kultury.

Witos, Wincenty. 1947. „Dawniej a teraz”. W Wybór pisaray ludowych. T. I. Oprac. Stanisław Pigoń. Wrocław: Ossolineum.

Witos, Wincenty. 1947a. „Oświata przelewa się przez brzegi”. W Wybór pisarzy ludowych. T. I. Oprac. Stanisław Pigoń. Wrocław: Ossolineum.

Wołk-Gumplowiczowa, Wanda. 1939. Chłopi, mieszrzaństwo i szlachta w powieści polskiej w piernszej polowie XIX w. Warszawa: Nasza Księgarnia. 
Paweł Tomczok - dr, adiunkt w Zakładzie Historii Literatury Poromantycznej Uniwersytetu Śląskiego w Katowicach. Autor książki Literacki kapitalizm. Obrazy abstrakcji ekonomicznych w literaturze polskiej drugiej potowy XIX wieku (w przygotowaniu). Zajmuje się ekonomia literatury.

\section{DANE ADRESOWE:}

Instytut Nauk o Literaturze Polskiej im. I. Opackiego

Uniwersytet Śląski

40-032 Katowice

pl. Sejmu Śląskiego 1

EMAIL: tomczok@wp.pl

CYTOWANIE: Tomczok, Paweł. 2017. „Pańszczyzna i przemoc. Historie literackie i wspomnieniowe z XIX wieku.” Praktyka Teoretyczna 1(23): 237-266.

DOI: $10.14746 /$ prt.2017.1.9

FINANSOWANIE: Artykuł powstał w ramach projektu Ekonomia literatury, który został sfinansowany ze środków Narodowego Centrum Nauki, przyznanych na podstawie decyzji nr DEC-2012/05/D/HS2/03589.

AUTHOR: Paweł Tomczok

TITLE: Villein (serfdom) and Violence. Literary and Memorial Histories from the 19th century

ABSTRACT: This article presents a model of villein-inflicted violence on the basis of 19th century realist novels and the peasant memory of the experience of serfdom. This article brings two disparate bodies of literature together in order to bring to light continuities in the relationship of work and violence across serfdom and capitalism in 19th century Poland. First, the article examines a number of realist novels which do not directly address serfdom amongst its central themes and thus, the representation of villein (serfdom) violence has to be sought at the borders of the world inhabited by the work's protagonists, usually from the perspective of privileged classes. As such, the problem of serfdom is visible only indirectly, in the form of short fragments of well-known novels. At the same time, these works assume the obviousness of violence against peasants. This article offers an analysis of Polish realist tradition of fiction writing in order to demonstrate how the very social standing of protagonists is maintained at the expense of the people doing physical labor. Second, the article examines descriptions of this violence in the memoirs of peasants, and further offers 
an analysis of two such examples of the suppression of peasant revolt through physical violence. Deprived of all hope and agency, victims were left only to submit to the coercion of work in total resignation. Bringing these two bodies of literature together reveals the nexus of work and violence which, instead of disappearing with the abolition of villein (serfdom), emerged in the form of new capitalist relationships defined by inequalities between the capitalist and the proletarian.

KEYWORDS: villein, violence, realistic novel, memories of the peasants 